\title{
Kolonisasi Beberapa Jamur Antagonis Pada Akar Tanaman Cabai (Capsicum annuum L.) dan Pengaruhnya Terhadap Penekanan Penyakit Antraknosa yang Disebabkan Oleh Colletotrichum gloeosporioides
}

\author{
Nurbailis, Yunisman, Lusi Aprilia \\ Jurusan Proteksi Tanaman Fakultas Pertanian Universitas Andalas Padang \\ Email : nurbailisjamarun@yahoo.co.id
}

\begin{abstract}
ABSTRAK
Penyakit antraknosa merupakan penyakit penting pada tanaman cabai yang disebabkan oleh Colletotrichum gloesporioides. Penelitian ini bertujuan untuk mendapatkan jamur antagonis unggul yang mampu mengkolonisasi akar tanaman cabai dan efektif mengendalikan penyakit antraknosa yang disebabkan oleh Colletotrichum gloesporioides. Metode penelitian menggunakan Rancangan Acak Kelompok (RAK) dengan 10 perlakuan dan 4 ulangan. Jamur antagonis yang digunakan yaitu: Trichoderma isolat 1, Trichoderma isolat 2, Trichoderma isolat 3, Trichoderma isolat 4, Paecilomyces isolat 1, Paecilomyces isolat 2, Paecilomyces isolat 3, Paecilomyces isolat 4, dan Aspergilus sp. Aplikasi jamur antagonis dilakukan dengan merendam akar tanaman cabai pada suspensi jamur dan aplikasi jamur patogen dilakukan dengan menyemprotkan suspensi jamur pada buah cabai sampai seluruh permukaannya basah. Hasil penelitian menunjukkan bahwa semua jamur antagonis yang diuji mampu mengkolonisasi akar tanaman cabai. Isolat yang terbaik dalam mengkolonisasi dan penekanan penyakit antraknosa adalah Trichoderma isolat 3 yang memiliki kemampuan kolonisasi sebesar 95,83\%, persentase buah terserang 18,75\% dan intensitas serangan sebesar 20\% dan Trichoderma isolat 1 memiliki kemampuan kolonisasi sebesar $91,66 \%$, persentase buah terserang $25,00 \%$ dan intensitas serangan sebesar $32,50 \%$.
\end{abstract}

Kata kunci: Aspergilus sp., kolonisasi, Paecilomyces Trichoderma

\section{PENDAHULUAN}

Penyakit antraknosa (busuk buah) merupakan salah satu penyakit penting dan sangat merugikan pada tanaman cabai. Penyakit ini disebabkan oleh Colletotrichum gloeosporioides dan Colletotrichum capsici (Kim et al., 2004). Penyakit antraknosa sulit dikendalikan karena patogen memiliki keragaman genetik yang tinggi (Than et al, 2008).

Pengendalian penyakit antraknosa saat ini masih mengutamakan penggunaan pestisida sintetik, penggunaan secara terusmenerus dapat menimbulkan berbagai dampak negatif terhadap lingkungan dan konsumen. Untuk itu perlu dicari alternatif pengendalian lain yang ramah lingkungan yaitu dengan metode pengendalian hayati dengan memanfaatkan jamur yang bersifat antagonis terhadap patogen.
Beberapa jamur antagonis telah dilaporkan efektif dalam mengendalikan patogen pada tanaman seperti Trichoderma, Aspergillus dan Paecilomyces. Hasil penelitian Nurbailis dan Martinius (2014), menunjukkan bahwa 52 isolat jamur yang berasal dari rizosfir cabai ditemukan 9 isolat yang berpotensi menghambat pertumbuhan $C$. gloeosporoides penyebab anatraknos pada cabai. Hasil identifikasi menunjukkan bahwa 9 isolat tersebut di atas tergolong ke dalam 4 isolat Trichoderma, 4 isolat Paecilomyces dan satu isolat Aspergillus. Menurut Zivkovic et al. (2010) jamur antagonis T. harzanium dapat menghambat pertumbuhan miselium dan perkecambahan konidia dari $C$. gloeosporioides dan C. acutatum. Kalay et al. (2008) melaporkan bahwa jamur Paecilomyces lilacianus dapat mengendalikan nematoda Globodera rostochiensis pada tanaman kentang secara 
in vitro. Nurzannah et al. (2014) menyatakan bahwa dari beberapa jamur yang digunakan untuk mengendalikan layu fusarium pada cabai, perlakuan dengan jamur Aspergilus sp. menunjukkan persentase serangan yang tinggi sehingga tidak mampu mengendalikan Fusarium oxysporum. Well (1986) menyatakan bahwa Trichodrma spp merupakan jamur yang umum terdapat dalam tanah dan dapat tumbuh dengan cepat dalam berbagai substrat. Menurut McClenny (2005) Genus Aspergillus merupakan genus yang dapat ditemukan pada berbagai habitat dan tumbuh cepat pada medium yang kaya akan carbon.

Beberapa hasil penelitian menunjukkan bahwa tingkat kolonisasi akar oleh Trichoderma spp. sangat menentukan keberhasilan pengendalian patogen tanaman. Demeyer et al. (1998) melaporkan bahwa keberhasilan $T$. harzianum strain $\mathrm{T}$ 39 dalam pengendalian $C$. lindemuthianum dan Botritys cinerea pada tanaman buncis disebabkan kemampuan isolat tersebut mengkolonisasi akar tanaman buncis. Menurut Harman (2000), Trichoderma adalah salah satu jamur tanah yang bersifat antagonis terhadap patogen tular tanah bahkan telah dilaporkan juga bahwa jamur ini mampu menginduksi ketahanan terhadap berbagai penyakit tanaman. Yedidia et al.(1999) melaporkan bahwa beberapa strain Trichoderma mampu mengkolonisasi dan bersifat endofit pada jaringan akar bibit mentimun yang menyebabkan terjadinya peningkatan aktivitas senyawa ketahanan pada akar dan daun tanaman. Vasantahakumari dan Shivanna (2013) melaporkan bahwa dari 138 isolat jamur yang berasal dari rizosfir dan rizoplan tanaman rumput ada 15 isolat yang menghambat pertumbuhan $C$. capsici penyebab penyakit antraknosa pada cabai. Isolat tersebut juga mampu mengkolonisasi akar cabai.

Nurbailis et al. (2014) melaporkan sembilan isolat jamur antagonis yang berasal dari rizosfir tanaman cabai berpotensi menghambat pertumbuhan $C$. gloeosporioides dengan mekanisme antagonisme yang beragam seperti: kompetisi, antibiosis dan hiperparasit.
Pengembangan pemanfaatan jamur antagonis tersebut untuk pengendalian penyakit antraknosa pada cabai perlu diketahui kemampuan kolonisasinya pada akar cabai dan pengaruhnya terhadap penyakit antraknosa yang disebabkan oleh C. gloeosporiodes .

Penelitian ini bertujuan untuk mendapatkan jamur antagonis unggul yang mampu mengkolonisasi akar cabai dan efektif mengendalikan penyakit antraknosa yang disebabkan oleh C. gloeosporiodes.

\section{METODE PENELITIAN}

\section{Waktu dan Tempat}

Penelitian ini telah dilaksanakan dari Desember 2015 sampai Maret 2016 di Laboratorium Fitopatologi Jurusan Hama dan Penyakit Tumbuhan dan rumah kaca, Fakultas Pertanian Universitas Andalas.

\section{Metode Penelitian}

Penelitian ini terdiri dari 2 unit percobaan, yaitu: 1 . Pengujian kemampuan kolonisasi berbagai jamur antagonis pada akar cabai, 2. Pengaruh kolonisasi berbagai jamur antagonis pada akar cabai terhadap penekanan penyakit antraknosa pada cabai. Rancangan yang digunakan adalah Rancangan Acak Kelompok (RAK) yang terdiri dari 10 perlakuan dan 4 ulangan. Perlakuannya adalah Trichoderma isolat 1 , 2, 3 dan 4, isolate Paecilomyces isolat 1, 2, 3 dan 4, Aspergillus isolat 1 serta control. Data dianalisis secara statistik dengan analisis ragam dan dilanjutkan dengan uji Tukey pada taraf nyata $5 \%$.

\section{Pelaksanaan Penelitian \\ Perbanyakan isolat jamur antagonis}

Isolat jamur antagonis berasal dari rizosfir tanaman cabai di Sumatera Barat. Isolat disimpan dalam tabung reaksi yang berisikan medium PDA yang dimiringkan dan ditempatkan pada lemari es di laboratorium Fitopalogi Fakultas Pertanian Universitas Andalas Isolat dimurnikan kembali pada medium potato dextrose Agar (PDA). Untuk Trichoderma dan Aspergillus diinkubasi selama 6 hari sedangkan untuk Paecilomyces diinkubasi 14 hari. Sembilan isolat jamur antagonis 
yang digunakan dalam penelitian dapat dilihat pada Gambar 1.

\section{Penyediaan bibit cabai dan pemindahan ke media tanam}

Bibit cabai yang digunakan untuk penelitian adalah varietas lokal Padang yang berasal dari Petani cabai di daerah Kuranji. Bibit yang dipindahkan ke media tanam adalah bibit yang telah berumur 3 minggu. Media tanam terdiri dari campuran tanah dan pupuk kandang steril dengan perbandingan $(2: 1, \mathrm{v} / \mathrm{v})$ Jumlah media tanam yang disiapkan yaitu 200 polibag, 160 polibag berukuran $1 / 2 \mathrm{~kg}$ untuk pengamatan kolonisasi jamur antagonis pada bibit cabai dan 40 polibag berukuran $10 \mathrm{~kg}$ untuk pengamatan perkembangan penyakit antraknosa pada buah cabai, selanjutnya dilakukan pemeliharaan (penyiangan gulma, pemupukan dan penyiraman).

\section{Persiapan Jamur patogen $C$. gloeosporioides}

Jamur patogen berasal dari tanaman cabai yang terinfeksi $C$. gloesporioides hasil penelitian sebelumnya. Jamur tersebut dikoleksi di Laboratorium Fitopatologi
Fakultas Pertanian Universitas Andalas. Jamur tersebut dibiakkan kembali pada media PDA dan diinkubasi selama 14 hari.

\section{Penyediaan suspensi konidia jamur antagonis dan jamur patogen $C$. gloeosporioides}

Suspensi konidia jamur dibuat dengan menambahkan $10 \mathrm{ml}$ akuades steril kedalam masing-masing cawan petri yang berisi biakan jamur. Konidia dilepas menggunakan kuas halus dan didapatkan suspensi jamur. Kemudian suspensi dipindahkan ke tabung reaksi lalu dihomogenkan menggunakan vortex.Dari suspensi tersebut diambil $1 \mathrm{ml}$ dengan pipet tetes dan dihitung jumlah konidia dengan menggunakan haemocytometer. Konsentrasi yang digunakan untuk perlakuan adalah $10^{6} \mathrm{konidia} / \mathrm{ml}$ suspensi.

\section{Perlakuan bibit cabai}

Bibit yang telah berumur 3 minggu sebelum dipindahkan ke dalam polibag terlebih dahulu diberi perlakuan dengan

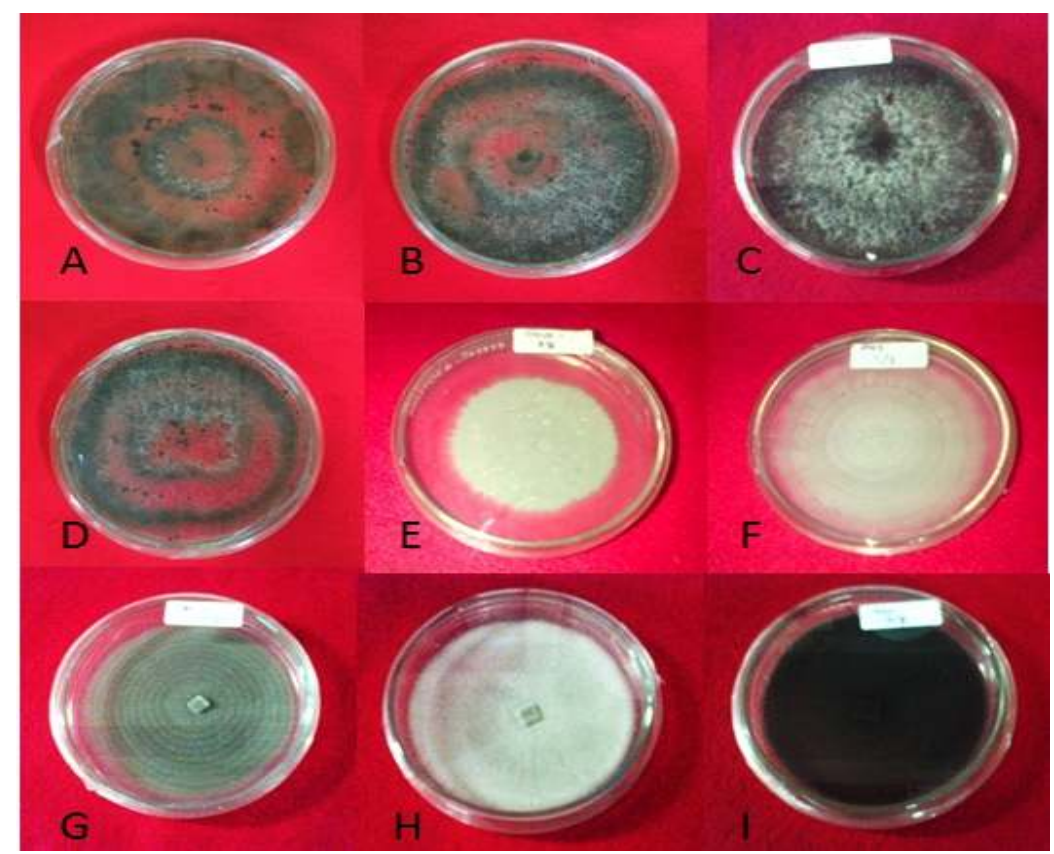

Gambar 1. Isolat jamur antagonis pada media PDA. A. Trichodema isolate, B. Trichodema isolat 2, C. Trichodema isolat 3, D. Trichodema isolat 4, E. Paecilomyces isolate 1, F. Paecilomyces isolat 2, G. Paecilomyces isolat 3, H. Paecilomyces isolat 4, I. Aspergillus isolat 1. 
merendam akar bibit cabai ke dalam suspensi konidia jamur antagonis selama 15 menit, selanjutnya bibit ditanam di dalam polibag yang berisi media tanam yang telah dipersiapkan dan dipelihara sampai berbuah.

\section{Inokulasi patogen $C$. gloeosporioides}

Buah cabai yang diberi perlakuan adalah buah yang telah berumur 1 bulan setelah pembungaan. Sebelum dilakukan inokulasi patogen, permukaan buah cabai dilukai dengan cara menusuk permukaan buah menggunakan jarum pentul, sebanyak 3 tusukan untuk setiap buah. Inokulasi dilakukan dengan cara menyemprotkan suspensi jamur patogen $C$. gloeosporioides $\left(10^{6} \quad \mathrm{konidia} / \mathrm{ml}\right)$ sampai seluruh permukaannya buah basah (Nurbailis dan Martinius, 2015)

\section{Pengamatan}

Kolonisasi jamur antagonis pada akar cabai

Kemampuan kolonisasi jamur antagonis pada akar cabai ditentukan mulai dari 7 hari setelah aplikasi jamur antagonis pada akar bibit cabai sampai 28 hari setelah aplikasi dengan interval waktu pengamatan 7 hari. Tingkat kolonisasi ditentukan dengan metode yang dikemukakan oleh Ozbay dan Newman (2004) yaitu dengan membuat fragmentasi akar bibit cabai. Akar dipotong-potong sepanjang $\pm 1 \mathrm{~cm}$, kemudian potongan akar ditempatkan didalam cawan petri yang telah berisi media PDA, setiap cawan petri berisi 6 potongan akar.Akar cabai dinyatakan dikolonisasi oleh jamur antagonis apabila dari potongan akar tumbuh koloni jamur antagonis.

Kolonisasi jamur antagonis pada akar cabai dihitung dengan menggunakan rumus:

Keterangan:

$$
\mathrm{K}=\frac{\mathrm{A}}{\mathrm{B}} \times \mathbf{1 0 0 \%}
$$

$\mathrm{K}=$ Kolonisasi jamur antagonis

$\mathrm{A}=$ Jumlah koloni jamur antagonis yang tumbuh pada potongan akar cabai

$\mathrm{B}=$ Jumlah seluruh potongan akar yang diamati

\section{Perkembangan penyakit antaknosa pada buah cabai}

\section{Munculnya gejala pertama penyakit antraknosa \\ Munculnya gejala pertama penyakit} antraknosa pada buah cabai diamati mulai 2 hari sampai 28 hari setelah inokulasi patogen pengamtan dilakukan setiap hari.

\section{Persentase buah terserang penyakit antraknosa \\ Pengamatan persentase buah} terserang dilakukan mulai 7 hari sampai 28 hari setelah inokulasi patogen i. Persentase buah terserang dihitung menggunakan rumus (Hidayat, 1998):

Keterangan:

$$
\mathrm{P}=\frac{\mathrm{JBS}}{\mathrm{JBK}} \times 100 \%
$$

$\begin{aligned} \mathrm{P}= & \text { Persentase buah terserang } \\ & \text { penyakit antraknosa } \\ \text { JBS }= & \text { Jumlah buah yang bergejala } \\ & \text { antraknosa } \\ \text { JBK }= & \text { Jumlah seluruh buah yang diamati }\end{aligned}$

Intensitas serangan penyakit antraknosa Intensitas serangan penyakit antraknosa ditentukan dengan menggunakan rumus (Zadoks dan Schein, 1979) sebagai berikut:

Keterangan:

$$
\mathrm{I}=\sum \frac{n i x v i}{N \times V} \times 100 \%
$$

$$
\begin{aligned}
\mathrm{I}= & \text { Intensitas } \\
\text { antraknosa } & \text { seranganpenyakit } \\
\mathrm{ni}= & \begin{array}{l}
\text { Jumlah buah yang sakit dengan } \\
\text { skala } \mathrm{i}
\end{array} \\
\mathrm{vi}= & \begin{array}{l}
\text { Skor tiap kategori buah yang } \\
\text { diamati }
\end{array} \\
\mathrm{N}= & \text { Jumlah seluruh buah yang diamati } \\
\mathrm{V}= & \text { Skor serangan tertinggi }
\end{aligned}
$$

Nilai kategori serangan (skor) untuk penyakit antraknosa didasarkan pada skala kerusakan tanaman yang terserang penyakit antraknosa (Herwidyarti, 2013). Nilai kategori serangan (skor) sebagai berikut:

$0=\underset{\text { tidak ada }}{\text { antraknosa y }}$ gejala penyakit




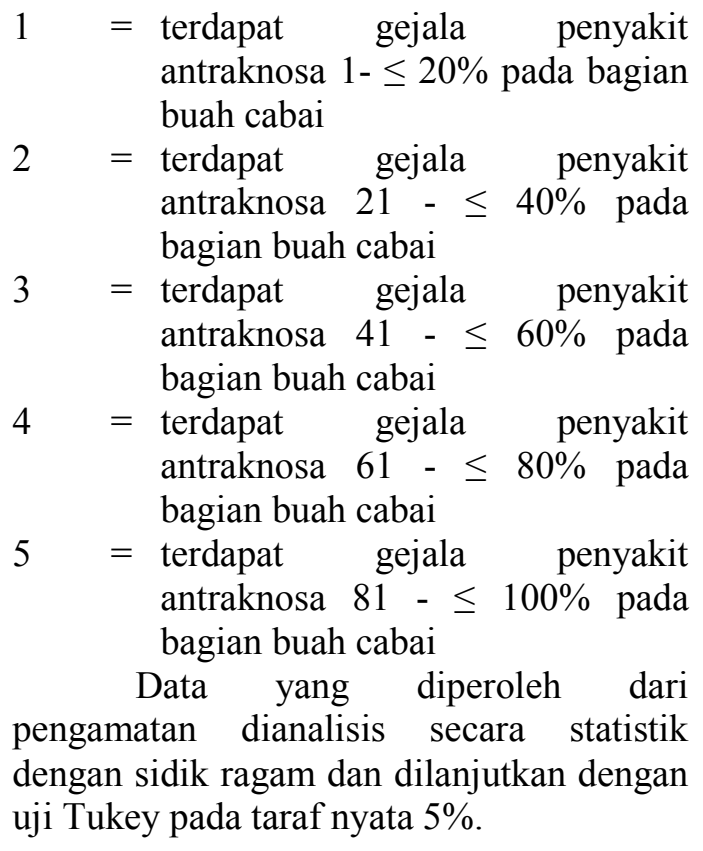

\section{HASIL DAN PEMBAHASAN}

\section{A. Hasil}

\section{Kolonisasi BeberapaJamur Antagonis pada Akar Cabai}

\section{a. Tingkat kolonisasi}

Kemampuan kolonisasi jamur antagonis pada buah cabai berbeda nyata antar perlakuan. Hasil uji lanjut dapat dilihat pada Tabel 1. Secara umum semua isolat jamu antagonis mampu mengolonisasi akar tanaman cabai. Tingkat kolonisasi yang tertinggi terdapat pada perlakuan dengan isolat dari genus Trichoderma dan Aspergillus (Tabel 1).

\section{Perkembangan kolonisasi beberapa jamur antagonis pada akar tanaman cabai}

Secara umum kolonisasi jamur antagonis pada akar tanaman mengalami peningkatan setiap minggu. Peningkatan yang tinggi terdapat pada isolat dari genus Trichoderma (Gambar 4).

Dari Gambar 4 dapat kita lihat bahwa perkembangan kolonisasi jamur antagonis berbeda. Trichoderma isolat 3 menunjukkan tingkat kolonisasi yang tertinggi setiap minggunya dimulai pada minggu pertama sebesar $66,66 \%$ dan terus naik setiap minggunya hingga mencapai angka sebesar 95,83\% pada minggu ke-4. Trichodermaisolat 2 dan Aspergilus sp. memiliki kemampuan kolonisasi berbeda pada minggu pertama Trichoderma isolat 2 tingkat kolonisasinya sebesar $58,33 \%$ dan Aspergilus sp. adalah 50,00\% namun pada minggu ke-4 memiliki tingkat kolonisasi yang sama yaitu sebesar $87,49 \%$

Tabel 1. Kolonisasi beberapa jamur antagonis pada akar tanaman cabai 28 hari setelah aplikasi

\begin{tabular}{lc}
\hline Perlakuan & Kemampuan Kolonisasi \\
\hline Trichoderma isolat 3 & $95,83 \mathrm{a}$ \\
Trichoderma isolat 1 & $91,66 \mathrm{a}$ \\
Trichoderma isolat 2 & $87,49 \mathrm{a}$ \\
Aspergilus isolat 1 & $87,49 \mathrm{a}$ \\
Trichoderma isolat 4 & $83,33 \mathrm{ab}$ \\
Paecilomyces isolat 1 & $79,16 \mathrm{abc}$ \\
Paecilomyces isolat 4 & $74,99 \mathrm{abc}$ \\
Paecilomyces isolat 2 & $58,33 \mathrm{bc}$ \\
Paecilomyces isolat 3 & $54,16 \mathrm{c}$ \\
\hline
\end{tabular}

KK=15,52

Angka-angka yang terletak pada lajur yang sama diikuti huruf kecil yang sama berbeda tidak nyata menurut uji Tukey pada taraf nyata 5\%. 


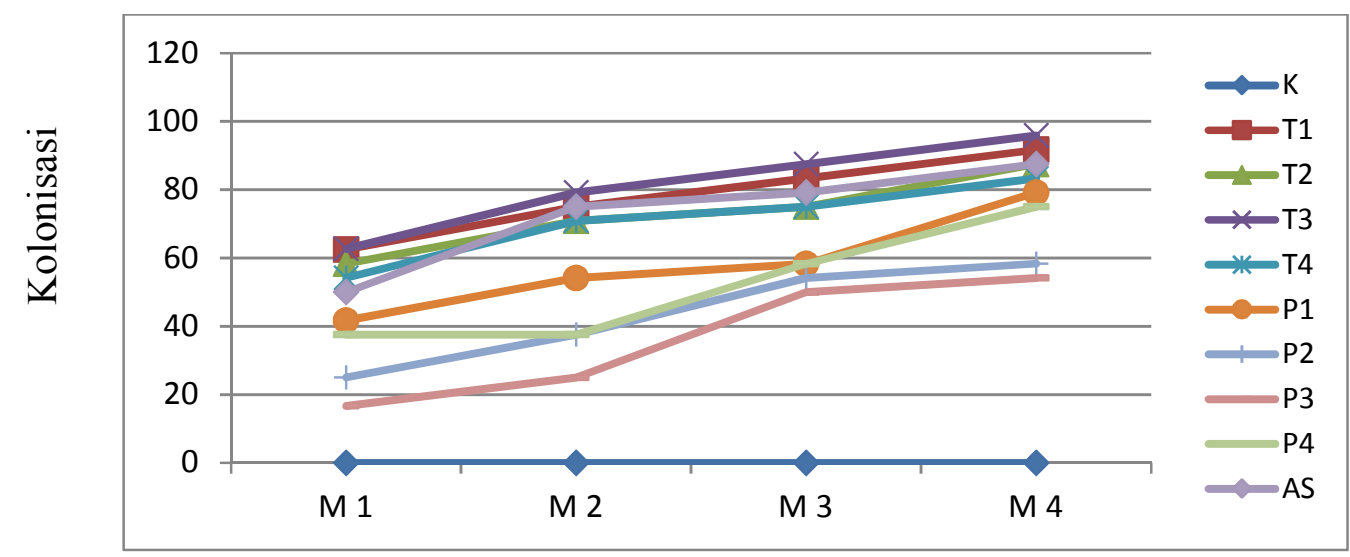

Gambar 4. Perkembangan kolonisasi beberapa jamur antagonis pada akar cabai pada minggu ke 1-4.K= Kontrol, T1-T4= Trichoderma, $\mathrm{P} 1-\mathrm{P} 4=$ Paecilomyces, $\mathrm{AS}=$ Aspergilus $\mathrm{sp}$.

Perkembangan Penyakit Antraknosa pada Buah Cabai

\section{Munculnya gejala pertama penyakit antraknosa.}

Munculnya gejala pertama, persentase buah yang terserang dan intensitas serangan penyakit antraknosa pada buah cabai memperlihatkan hasil yang berbeda nyata. Hasil uji lanjut dapat dilihat pada Tabel 2.

Gejala pertama penyakit antraknosa yang paling cepat muncul adalah pada perlakuan control dan perlakuan dengan
Aspergillus yaitu 4 hari setelah inkulasi, sedangkan yang paling lama muncul adalah pada perlakuan Trichoderma isolat 3 yaitu 11.50 hari setelah inokulasi.

Secara umum persentase buah terserang yang rendah terdapat pada perlakuan dengan genus Trichoderma. Perlakuan dengan genus Paecilomyces tingkat serangannya cukup tinggi yaitu: 50$75 \%$. Persentase serangan yang paling rendah terdapat pada perlakuan Trichoderma isolat 3 yaitu: $18,75 \%$ dan diikuti oleh Trichoderma isolat 1 yaitu: $25 \%$. Intensitas serangan penyakit

Tabel. 2 Serangan Penyakit Antraknosa pada Buah Cabai meliputi Munculnya Gejala Pertama Persentase dan Intensitas buah cabai terserang dengan Perlakuan berbagai Jamur Antagonis

\begin{tabular}{|c|c|c|c|c|c|c|c|}
\hline & \multirow[b]{2}{*}{ Perlakuan } & \multicolumn{6}{|c|}{ Serangan Penyakit Antraknosa pada Buah Cabai } \\
\hline & & \multicolumn{2}{|c|}{$\begin{array}{c}\text { Munculnya Gejala } \\
\text { pertama }\end{array}$} & \multicolumn{2}{|c|}{$\begin{array}{l}\text { Persentase Buah } \\
\text { Terserang }\end{array}$} & \multicolumn{2}{|c|}{$\begin{array}{c}\text { Intensitas Buah } \\
\text { Terserang }(\%)\end{array}$} \\
\hline 1 & Trichoderma isolat 1 & 11.50 & & 25.00 & $\mathrm{~d}$ & 32.50 & $\mathrm{~d}$ \\
\hline 2 & Trichoderma isolat 2 & 9.00 & $\mathrm{~b}$ & 50.00 & $\mathrm{~d}$ & 41.25 & $\mathrm{~cd}$ \\
\hline 3 & Trichoderma isolat 3 & 7.00 & $\mathrm{c}$ & 18,75 & $\mathrm{~d}$ & 20.00 & $\mathrm{~d}$ \\
\hline 4 & Trichoderma isolat 4 & 6.00 & $\mathrm{~cd}$ & 31.25 & $\mathrm{~d}$ & 40.00 & $\mathrm{~cd}$ \\
\hline 5 & Paecilomyces isolat 1 & 5.75 & $\mathrm{~cd}$ & 50.00 & $\mathrm{c}$ & 67.50 & $\mathrm{~b}$ \\
\hline 6 & Paecilomyces isolat 2 & 5.75 & $\mathrm{~cd}$ & 68.75 & $\mathrm{~b}$ & 72.50 & $\mathrm{~b}$ \\
\hline 7 & Paecilomyces isolat 3 & 5.25 & $\mathrm{~cd}$ & 50.00 & $\mathrm{c}$ & 61.25 & bc \\
\hline 8 & Paecilomyces isolat 4 & 5.25 & $\mathrm{~cd}$ & 75.00 & $\mathrm{~b}$ & 73.75 & $\mathrm{~b}$ \\
\hline 9 & Aspergillus isolat 1 & 4.00 & e & 100.00 & $\mathrm{a}$ & 100 & a \\
\hline 10 & Kontrol & 4.00 & $\mathrm{e}$ & 100.00 & $\mathrm{a}$ & 100 & \\
\hline $\mathrm{KK}$ & & 10.28 & & 13.55 & & 15.46 & \\
\hline
\end{tabular}

Angka-angka yang terletak pada lajur yang sama diikuti huruf kecil yang sama berbeda tidak nyata menurut uji Tukey pada taraf nyata $5 \%$. 
Jurnal Proteksi Tanaman

Journal of Plant Protection ISSN : 2580-0604
Vol 1 No.1 (2017): 1 - 9

Website: http://jpt.faperta.unand.ac.id/index.php/jpt antraknosa tertinggi terdapat pada perlakuan kontrol yaitu $100 \%$ dan diikuti oleh Aspergillus sp. yaitu 96,25\%. Intensitas serangan yang rendah terdapat pada perlakuan dengan genus Trichoderma. Perlakuan dengan genus Paecilomyces intensitas serangannya cukup tinggi yaitu: $61,25-73,75 \%$. Intensitas serangan yang paling rendah terdapat pada perlakuan Trichoderma isolat 3 yaitu: $20 \%$ dan Trichodermaisolat 1 yaitu: $32,50 \%$.

\section{Pembahasan}

Pengamatan tingkat kolonisasi beberapa jamur antagonis pada akar cabai menunjukkan bahwa secara umum sembilan isolat jamur antagonis mampu mengkolonisasi akar cabai. Tingkat kolonisasi yang tertinggi terdapat pada perlakuan Trichoderma isolat 3 kemudian diikuti oleh Trichoderma isolat 1, Trichoderma isolat 2 dan Aspergilus sp. Kemampuan dari masing-masing isolat jamur antagonis dalam mengkolonisasi akar cabai berbeda-beda. Hal ini berkaitan dengan perbedaan karakter dari masing masing jamur antagonis. Trichoderma dan Aspergillus merupakan jamur antagonis yang mempunyai pertumbuhan yang lebih cepat dibanding dengan jamur Paecilomyces. Kedua jamur ini juga dapat tumbuh dengan cepat pada berbagai substrat. (Well, 1986; Mc Clenny, 2005). Tingkat kolonisasi jamur Paecilomyces menunjukkan hasil yang lebih rendah dibandingkan dengan jamur Trichoderma dan Aspergilus sp. Hal ini diduga berhubungan dengan lamanya pertumbuhan jamur tesebut yang dibiakkan pada media PDA mampu tumbuh memenuhi cawan petri dalam waktu 10-14 hari.

Kolonisasi jamur antagonis pada akar tanaman cabai ternyata berpengaruh pada perkembangan penyakit antraknosa. Aplikasi Trichoderma isolat 3 dan Trichoderma isolat 1 mampu memperlambat masa inkubasi, persentase buah terserang dan intensitas serangan yang lebih rendah bila dibandingkan dengan perlakuan jamur lainnya. Hal ini disebabkan oleh jamur antagonis tersebut dapat mengkolonisasi akar bibit cabai dengan baik. Harman et al. (2004) melaporkan bahwa Trichoderma spp. merupakan salah satu jamur saprofit yang hidup pada rizosfir tanaman. Jamur ini dapat mengkolonisasi dan tumbuh pada sistem perakaran berbagai tanaman. Kemampuan kolonisasi yang baik pada Trichoderma tersebut diduga dapat menimbulkan induksi ketahanan pada tanaman cabai.

Jamur Trichoderma dapat masuk ke dalam jaringan tanaman atau bersifat endofit pada jaringan tanaman cabai. Dari beberapa hasil penelitian diketahui bahwa jamur antagonis yang bersifat endofit pada jaringan tanaman dapat menyebabkan terinduksinya ketahanan tanaman terhadap berbagai patogen. Yedidia et al., (1999) melaporkan bahwa beberapa strain Trichoderma mampu mengkolonisasi dan bersifat endofit pada jaringan akar bibit mentimun yang menyebabkan terjadinya peningkatan aktivitas senyawa ketahanan pada akar tanaman. Demeyer et al. (1998) melaporkan bahwa keberhasilan $T$. harzianum strain T-39 dalam pengendalian C. lindemuthianum dan Botritys cinerea pada tanaman buncis disebabkan kemampuan isolat tersebut mengkolonisasi akar tanaman buncis.

Pada perlakuan jamur antagonis Aspergilus sp. yang memiliki kemampuan kolonisasi yang cukup tinggi memperlihatkan hasil yang tidak relevan dengan kemampuannya dalam menekan penyakit antraknosa. Hal ini dapat dilihat dari tingginya persentase buah terserang dan intensitas serangan penyakit antraknosa. Diduga jamur tersebut tidak mampu menginduksi ketahanan tanaman dan tidak bersifat endofit pada jaringan akar tanaman cabai. Nurzannah et al. (2014) menyatakan bahwa dari beberapa jamur yang digunakan untuk mengendalikan layu fusarium pada cabai, perlakuan dengan jamur Aspergilus sp. menunjukkan persentase serangan yang tinggi sehingga tidak mampu mengendalikan Fusarium oxysporum. Perlakuan dengan menggunakan jamur antagonis 
Paecilomyces menunjukkan bahwa jamur tersebut belum efektif dalam menekan penyakit antraknosa. Hal ini berhubungan rendahnya kemampaun kolonisasi jamur ini pada akar tanaman cabai, jamur ini juga belum dilaporkan bersifat endofit pada jaringan tanaman.

\section{KESIMPULAN}

Semua jamur antagonis yang diuji mampu mengkolonisasi akar cabai dengan tingkat kolonisasi $54,16-95,83 \%$. Isolat yang terbaik dalam mengkolonisasi dan penekanan penyakit antraknosa adalah Trichoderma isolat 3 dan Trichoderma isolat 1

\section{DAFTAR PUSTAKA}

Demeyer, G., Bigirimana, J., Elad, Y. \& Hofte, M. 1998.Induced Systemic resistance in Trichoderma harzianum T39 Biocontrol of Botrytis cinerea, Eur. J. Plant Pathol, 104: 279-286.

Harman, G. E. 2000. Changes in Perceptions Derived from Research on Trichoderma harzianum T-22. Plant Disease / April 2000. Publication No. D-2000-0208-01F.

Herwidyarti, K.H., S. Ratih., dan D.R.J. Sembodo. 2013. Keparahan Penyakit Antraknosa Pada Cabai (Capsiccum annum L.) Dan Berbagai Jenis Gulma. J. Agrotek. Tropika. 1 (1): 102-106.

Hidayat, I.M., I. Sulastrini., Y. Kusandriani dan A.H. Permadi. 2004. Lesio Sebagai Komponen Tanggap Buah 20 Galur dan Varietas Cabai Terhadap Inokulasi Colletotrichum capsici dan Colletotrichum gloeosporioides. J. Hort. 14 (3): 161-162.

Kalay, A., S. Natasasmita., T. Suganda dan T. Simarmata. 2008. Uji Parasitik Beberapa Spesies Jamur Tanah Terhadap Globodera rostochiensis (woll) Secara In Vitro. J. Natur Indonesia 10 (2): 73-75.
Kim, K.H, J. B. Yoon, E. W. Park and Y.H. Kim. 2004. Structure Modification and Programmed Cell Death of Chilli Pepper Fruit Related to Resistance Responses to Colletotrichum gloesporiodes Infection. J. Phytopathology. $82: 213-225$.

McClenny, N. (2005) Laboratory Detection and Identification of Aspergillus Species by Microscopic Observation and Culture: The Traditional Approach. J. of Medical Mycology, 43: 125-128.

Nurbailis., Martinius dan V. Azniza. 2014.Keanekaragaman Jamur Saprofit Pada Rizosfir Tanaman Cabai Sistem Konvensional dan Organik Yang Berpotensi Mengendalikan Colletotrichum spp. Penyebab Penyakit Antraknosa Pada Cabai. J.HPT Tropika. 14 (1): 16-24.

Nurbailis dan Martinius. 2015. Pemanfaatan jamur antagonis indigenus rizosfir cabai untuk pengendalian hayati penyakit antraknosa yang disebabkan oleh Colletotrichum gloeosporoides Laporan Penelitian Hibah Bersaing. Padang

Nurzanah, E. S, Lisnawita dan Bakti, D. 2014. Potensi Jamur Asal Cabai Sebagai Agens Hayati Untuk Mengendalikan Layu Fusarium (Fusarium oxysporum) pada Cabai dan Interaksinya. J. Online Agroekoteknologi. 2 (3): 12301238.

Ozbay, N. \& Newman, S.E.2004.Biological Control withTrichoderma spp. With Emphasis on T. harzianum. Pakistan Journal of Biological Sciences 7 (4): 478-448.

Than PP, Prihastuti H, Phoulivong S, Taylor P, \& Hyde KD. 2008. Chilli anthracnose disease caused by Colletotrichum species. J Zhejiang Univ Sci B 9(10): 764778 . 
Yedidia, I., Benhamou, N. \& Chet, I. 1999.Induction of Defence Responces in Cucumber Plants (Cucumis sativus, L) by The Biocontrol Agens Trichoderma harzianum. Appl Environ Microbiology 65(3): 1061-1070.

Vasantahakumari, M.M. dan M.B Shivana. 2013. Biological Control of Antraknosa of Chili with Rizosphire and Rizoplan Fungal Isolate From Grasses. Archives of Phytopatology and Plant Protection 46 (14): 1641-1666.

Well HD. 1986. Trichoderma as a biocontrol agent. P. 72-82 in Mukerji KG and Garg KL (Eds)
Biocontrol of plant disease Vol. I CRC Press Inc. Boca Raton, Florida

Zadoks, J.C dan R.D. Schein. 1979. Epidemiology and Plant Disease Management. Oxford University Press: New York.

Zivkovic, S., Stojanovic, S., Ivanovic, Z., Vgavrilovic, S., Popovic, T., and Balaz, J. 2010. Screening of Antagonistic Activity of Microorganisme Against Colletotrichum acutatum and Colletotrichum gloesporioides. Arch. Biol. Sci., Belgrade, 62 (3): 611-623 